ljtihad: Jurnal Wacana Hukum Islam dan Kemanusiaan

Vol. 19, No. 2 (2019), pp. 169-183 doi : 10.18326/ijtihad.v19i2.169-183

\title{
Reviewing shariah certificates of DSN MUI (a study on shariah certificate of DSN MUI on Paytren)
}

\author{
Muh. Nashirudin, Millatus Sa'adah \\ IAIN Surakarta \\ Email:muh.nashirudin@gmail.com,millatuss198@gmail.com \\ DOI: 10.18326/ijtihad.v19i2.169-183
}

Indonesian Ulama Council/Majelis Ulama Indonesia (MUI) has issued a fatwa which is related to Multi-Level Marketing (MLM). The fatwa number 75/VII/ 2009 concerns with Shariah Multilevel Direct Sale/Penjualan Langsung Berjenjang Syariah (PLBS) that requires a MLM company to fulfill twelve regulations to be categorized as shariah law-conformed and deserve to get a shariah business certificate. However, DSN-MUI has also issued a decree number No. KEP- 03/DSN-MUI/VII/ 2016 on the list of Shariah Multilevel Direct Sale companies and includes PT Veritra Santosa Internasional (VSI), which has sold Paytren application, as a shariah MLM with a decree number SK: 010.57.01/DSN-MUI/VII/2017. This study will discuss the consistency of DSN-MUI with its fatwa by analyzing the conformity between certificate of halal or shariah issued by DSN-MUI on Paytren and the fatwa of DSN-MUI on PLBS.

Majlis Ulama Indonesia (MUI) mengeluarkan fatwa terkait bisnis Multi Level Marketing (MLM) dengan Fatwa MUI No. 75/VII/2009 tentang Penjualan Langsung Berjenjang Syariah (PLBS) yang mensyaratkan adanya dua belas ketentuan yang harus dipenuhi oleh sebuah perusahaan MLM untuk bisa dikategorikan sesuai dengan syariah dan berhak mendapatkan sertifikasi bisnis syariah. Hanya saja, DSN-MUI menerbitkan Keputusan No. KEP-03/DSN-MUI/VII/2016 tentang daftar perusahaan penjualan langsung berjenjang syariah dan memasukkan PT Veritra Sentosa Internasional (VSI) yang menjual lisensi aplikasi Paytren dengan Nomor SK: 010.57.01/DSN-MUI/VIII/2017 dalam kategori MLM Syariah. Penelitian ini akan membahas konsistensi DSN MUI dengan fatwanya dengan menganalisis kesesuaian antara Sertifiikat Halal atau Syariah yang dikeluarkan oleh DSN MUI terkait Paytren dengan Fatwa DSN MUI tentang PLBS.

Keywords: fatwa consistency; shariah certificate; multi-level marketing 
Ijtihad: Jurnal Wacana Hukum Islam dan Kemanusiaan, Volume 19, №. 2, Desember 2019: 169-183

\section{Introduction}

Indonesian Council of Ulama/Majelis Ulama Indonesia (MUI), which is a media of discussion for ulama, moslem leaders, and moslem scholars is one of the most competent institutions in Indonesia to respond and answer social and religious problems faced by Indonesian moslem society (Amin, 2015: 20). MUI can be categorized as an institution which conducts ijtihâd jamầ or collective ijtihad on Islamic problems from various angles, such as aqîdah, ibâdah, social as well as national affairs, and even legislation (Nashirudin, 2017: 553). Collective ijtihad, according to al-Zuhaili (1996: 23), represents an ijtihad which is closer to the truth than an individual ijtihad ( $f a r d i)$ as it is conducted by compiling various opinions from individual ijtihad and after undergoing research, selection, considering various aspects, then taking the opinion which is the most credible, useful and related to the latest situation. The similar opinion has also been given by Yusuf al-Qardhawi who currently encourages more and more ijtihad because numerous contemporary problems have to be solved, one of which is by conducting ijtihâd jamâ' $̂$ by establishing fiqh institutions or fiqh forums (al-majma' al-fiqhì) consisting experts on their fields, especially in law to minimize individual ijtihad which deviates or go out of the principles of ijtihad determined by the ulama (al-Qardhawi, t.th.: 156).

One of the products of MUI which is always interesting to study is the halal certificate on a certain product issued by MUI after being approved as halal by Fatwa Committee of MUI. The approval of special fatwa, particularly about shariah economics which is related with the shariah finance products and services, is conducted by National Shariah Council (DSN-MUI).

The fatwa of MUI, especially halal certificate, will be very usefull to both producers and consumers of various fields, such as foods and bavereges, medicine field, and even in the field of services like shariah financial institutions. The label of halal on certain products will give huge benefits for the producers since the label indicates that the product is proper to be consumed by moslems. For the consumers, especially the moslems, this label guarantees the halal status of the products.

As a product of ijtihad, the fatwa of halal certificate issued by the Fatwa Committee of National Shariah Council has possibility to be reviewed. One of the example is the halal 
certificate issued by DSN-MUI with a decree number KEP-03/DSN-MUI/VII/2016 that categorizing Paytren as a Shariah Multilevel Direct Sale/Penjualan Langsung Berjenjang Syariah (PLBS) companies and it is deemed to conform with the principles of PLBS. MUI has already issued a fatwa on the principles of products of PLBS with a fatwa number 75/VII/2009. This paper analyzes the conformity of halal certificate issued by MUI towards Paytren with the fatwa number 75/VII/2009 about PLBS and also examines the consistency of MUI in issuing the fatwa.

In many studies about Multi-Level Marketing (MLM), there are some articles which can be used as sources of discussion; some of them are a book on title Multi-LevelMarketing Money Game dan Skema Piramid written by Purnomo, Serfianto D, Iswi Hariyani and Cita Yustisia which explains that shariah Multi-Level Marketing is not far different from conventional Multi-Level Marketing. What make them different is that the shariah MLM must qualify certain conditions. The product must be in good quality (thayib), halal, and there is no exploitation among human beings. The appreciation of the distributors complies with the principles of Islam such as avoiding coercion, dishonesty, and financial loss on other parties. Also, the price should not be costly although the bonus and commission are taken from the sales profit. Besides, the income distribution must be conducted professionally, and the contract must fulfill the norm and principles of transaction according to the Islamic law. The way the business run, policy, corporate culture, and also the accounting system must follow the shariah (Purnomo, 2011). This article does not specifically explain a certain MLM business, particularly Paytren, let alone viewing it from the fatwa perspective of DSN-MUI.

Samsul Muarif's article on title Konsep Multi-Level Marketing dalam Tinjauan Hukum Islam states that one of the method to market or distribute the product is by empowering the independent distributors without any interferences from the company. The system of multistage network does not influence the psychographic market segment for other members, and new members have equal opportunity to achieve higher level without any discrimination. The bonus system in MLM can be clearly seen and is far from uncertainty or free from gharar. This article only sees MLM from the perspective of Islamic law, and does not discuss about Paytren. 
Ijtihad: Jurnal Wacana Hukum Islam dan Kemanusiaan, Volume 19, No. 2, Desember 2019: 169-183

The article by Lilatur Rahmah on Bisnis Multi-Level Marketing Dalam Tinjanan Fatwa DSN MUI NO 75/DSN-MUI/VII/2009 (Studi Kasus Pada Member MLM 4jovem Di Situbondo) discusses the practice of 4jovem MLM in Situbondo to find out whether it conformed with fatwa of DSN-MUI number 75/DSN-MUI/VII/2009 about PLBS (Rahmah, 2017). Meanwhile, Ajeng Dwyanita (2014) and Irham Zaki's article which has a title Analisis Kesesuaian Syariah Pada Sistem Operasi Bisnis Multi-Level Marketing (MLM) KK Indonesia dengan Fatwa DSN MUINo 75/DSN-MUI/VII/2009, is different from the object of discussion in this article which highlights Paytren from the perspective of Fatwa of DSN MUI No:75/ DSN-MUI/VII/2009.

Multi-Level Marketing (MLM) is one kind of business which has strong relationship with buying and selling, so the buying and selling contract is employed. It must at least fulfill the principles and conditions of buying and selling. According to the majority of ulama, the principles of buying and selling are the parties involved (buyer and seller), sighat (the consent and the answer), the existence of the product, and the exchange value of the product (al-Zuhaili, 2005: 3309). Meanwhile, the conditions of buying and selling are attached to every aspect of the principles.

Etymologically, Multi-Level Marketing is derived from English word multi or many while level means stage. Meanwhile, marketing means to sell (Arum, 2012: 33). From those words, it can be concluded that Multi-Level Marketing is multi stage selling (Dewi, 2005: 188). It is called as multi-level since it is a distributor organization which conducts a multistage marketing (Harefa, 1994: 4).

The working mechanism of Multi-Level Marketing is a serial direct selling to the consumers who function as the product distributors and promote other people to join in order to enlarge the distribution network (Jauhari, 2013: 89). In other words, every distributor has two basic functions; to sell the products (goods and services) and to build distribution networks by recruiting other distributors to sell the products. Every newly- recruited distributor will be encouraged to recruit new distributors. The operational mechanism is that one distributor should invite other people to be new distributors (Dewanti, 2015: 57).

Since MLM scheme established well in Indonesia, National Shariah Council of Council of Indonesia Ulama (DSN-MUI) issued a fatwa of MUI number 75/VII/2009 on PLBS 
which was signed by K.H. Sahal Mahfudh, the chief of DSN-MUI, and H.M. Ichwan Sam, the secretary of DSN-MUI, on 25 July 2009 in Jakarta. The issuing of this fatwa is very urgent since there are many MLMs with various innovations and forms established, but there is no even a single regulation created to assess whether those businesses had already conformed to the principles of shariah, or not. Besides, it is the responsibility of DSN MUI to provide society a clear and pecise shariah guidance on a particular shariah-based economic business, including Shariah Multistage Direct Selling (Rahmah, 2017: 106).

In the fatwa of DSN-MUI number 75/VII/2009, there were twelve regulations to be fulfilled by a MLM company in order to be categorized as shariah-conformed and get a certificate of shariah business. Those regulations are as follows:

1. General Provisions

The general provisions based on the fatwa are:

a. The multistage direct selling is a means of selling good or service through marketing network which is conducted by a person or a company towards other persons or companies consecutively

b. Goods are every tangible item, either movable or unmovable, consumable or not, which is subject to possess, to sell, to use, to take benefit of by the consumers.

c. Services are every item of work or assistance which is used by consumers.

d. Company is an incorporated organization which conducts business activity of goods and services by using direct selling system according to the legal system.

e. Consumers are the users of the goods and services, and are not to be sold.

f. Commission is a reward given to the partner for every sale he or she has made in which the amount and the form is calculated from the volume and the value of the sales.

g. Bonus is an additional reward given by the company to the partner based on the sales which surpass the targets set by the company.

b. Igbrâ is an incredible interest which makes people careless toward their obligation in order to get bonus or commission when performing their jobs.

i. Money game is a fund raising activity or multiplying money by giving bonus and commission from the money obtained from the newly-recruited partners. It is not 
obtained from the sold products as the product merely function as a camouflage and or has low quality.

j. Excessive mark-up is the limit of profit which is far beyond normal and is connected to other things outside the cost.

k. Member get member is a strategy to recruit new members of multistage direct selling that has been conducted by the previous members.

1. Business partners or stockiest is a retailer who sells or offers the products directly.

2. Legal Regulations

There are twelve regulations for a MLM business to fulfil in order to be categorized as shariah and have rights to obtain shariah business certificate. Those are:

a. The existence of real transaction object which is either goods or services.

b. Goods and services which are offered are not considered haram or prohibited or are used for something considered as prohibited.

c. Transaction does not contain the element of gharar, maysir, riba, zulm, and ma'siyat or immorality.

d. There is no excessive mark up that will inflict financial loss to the customers as the product is not worth it for the quality or benefit.

e. The commission given to the members, both the amount and the variety should be based on the real achievement which is directly related with the volume or the value of the goods and the services. It also becomes the main income of the partners in MDS / MLM shariah.

f. The amount of the bonus given should be clear during the transaction and related to the sales target which has been set by the company.

g. There must not be any passive income which is achieved regularly without performing any selling activities.

h. 'The commission and bonus must avoid ighra' (giving an excessive promises) (Mandang, 2016: 108).

i. There must not be any exploitations or unfairness in the distribution of bonus for the first member and the next members.

j. The recruitment system, reward, and events related to this must not contain elements 
which are against aqidah, shariah, and good deeds.

k. Every business partners who recruit new members must guide and supervise them.

1. No money game (pure gambling which has no business form, either goods and services).

This study analyses the implementation of Paytren and overview it from the perspective of DSN-MUI on Shariah Multilevel Direct Sale/Penjualan Langsung Berjenjang Syariah (PLBS), and furthermore proves the consistency of DSN-MUI in issuing certificate of halal or shariah on Paytren. If all regulations listed in the fatwa of MUI SMDS are implemented well by Paytren, it deserves the certificate of shariah or certificate of halal. On the other hand, if those points are not fulfilled and at the same time Paytren is still deserved as halal, it means that DSN-MUI has issued a decision contradictory with its own fatwa..

A qualitative approach was chosen as the research method for this study. The process of research involves empirical work being carried out with the collection of data which can concur, refute or contest theories which in turn allows for understanding and clarification for multi-level marketing related issues. In capturing the issues, the researchers conducted a series of interview with Agus Aditya Kristianto, Sulhan Mahfud, Mochammad Rokim, and Deni Yasninta. The interviewees were purposively selected based on their hierarchical status and position as Paytren Gold, Star Leaders, Bronze Leader, and Basic, from which the issues of this research were discussed. Additional data also collected from writer's experience as one of Paytern's members. All data collected, then, were analyzed to investigate how the Multi-Level Marketing system of Paytren application take place and to what extent it is suitable with Islamic law in economic transactions. Religious decrees ( fatwa) by Indonesian Council of Ulama/Majelis Ulama Indonesia (MUI) were implemented in a comparative method with the research findings to uncover whether Paytren obey the fatwa concerning on Shariah Multilevel Direct Sale/Penjualan Langsung Berjenjang Syariah (PLBS) or not.

\section{Paytren at a glance}

Paytren is a digital payment application launched by ustadz Yusuf Mansur through a technology company developed by PT Veritra Santosa Internasional (Treni). This company offers and sells a payment application which is called Paytren. This application can be 
used for any payment transactions through smartphones which are registered on Treni community. To run this business, PT. Veritra Santosa Internasional gives two contracts or options toward Treni's special partner; as a user of Paytren or as a business person who sells and develops Treni community.

It is informed on http://www.trenpreneur.com/ that by installing Paytren, the users are able to perform various transactions via their gadgets such as buying cellular credit, token, airplane or train tickets, and paying various bills such as water, electricity, health insurance, internet, leasing, and others. All of those transactions can be performed anytime and anywhere.

In interview with Sulhan Mahfud, one of Paytren Star Leader, Paytren can be run by paying Rp 350,000,-to get a license and an activation code. After activating the membership, the user will get a partnership ID, PIN, and a password. Then he or she should download the Paytren application at Play store and enter license number.

Paytren, as cited from http://www.treni.co.id; https://paytren.co.id, offers two cooperation options, namely user partner and businessperson partner.

\section{Figure 1}

\section{The cooperation diagram of Paytren}

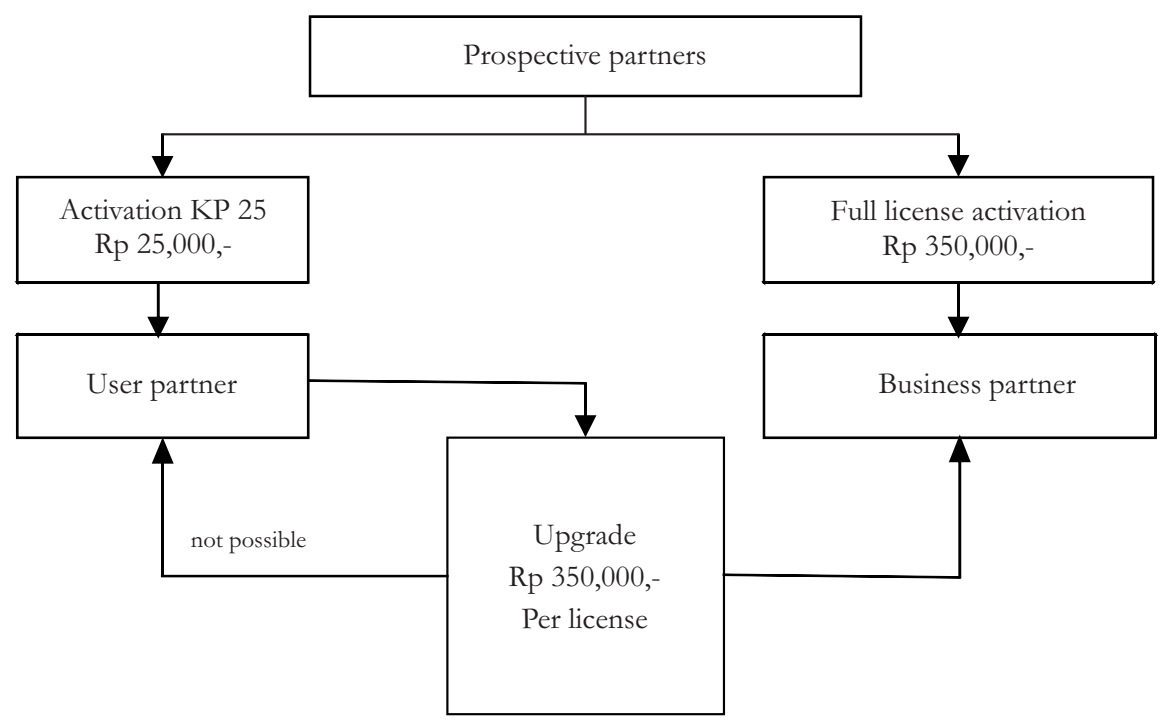


The user partners, as cited from http://paytrenluarbiasa.com, are those who have the rights to use title only or take the benefit of the products. Businessperson partners are those who have not only rights to use title but also rights to sell and develop their business at PT Veritra Santosa Internasional as well as to get various benefits such as commission or cashback. By purchasing a membership license worth Rp 350,000,- a user will get one operating rights (OR). The user who becomes the business partner of Paytren can register to the higher level by collecting 3 OR for silver level, 7 OR for gold level, 15 OR for platinum level, and 41 OR for titanium level and in addition, those licenses can be sold to the next recruited partners. This is why Paytren is considered to use MLM scheme in selling its licenses.

Paytren uses MLM scheme in its selling or marketing activity. It claims that this system does not belong to prohibited business. When other MLM businesses are considered as prohibited because of performing non-business operation, money games, and fraud, Paytren has products in payment services which give a lot of benefit and develop from time to time.

Another reason why conventional MLM system is considered prohibited is the use of closing point system which results in isro or buying unnecessary things excessively that will end up in redundancy. This is different from Paytren as stated by Mochammad Rokim, a bronze Paytren leader, that Paytren does not apply closing point system as a requirement to get the bonus, and furthermore it does not apply monthly target.

However, there are also some negative opinions about Paytren. One of them is Erwandi Tarmidzi, cited from http://erwanditarmizi.com/harta-haram-muamalat-kontemporer/, who states that Paytren is considered as prohibited. According to him, most people register for Paytren merely to get bonus instead of buying the products. Furthermore, he says that the market target of Paytren is not its payment services but the downline system. The more downline members acquired, the bigger the bonus opportunity achieved. In conclusion, people seek for the market opportunity, not the payment services.

Other negative opinions from several public figures such as Yusuf Somad, Khalid Basalamah, and Ami Nur Baits are also available in YouTube. Yusuf Somad says that Paytren contains gharar. According to him, the money used to register will be lost if the member is unable to get followers. Khalid Basalamah says MLM contains lies dealing 
with bonus and commission such as cars, motorcycles, and so on which will be given to members if they successfully recruit new members. In reality, they do not realize that they have already scored more than enough performance only from selling the license to the new members. Ami Nur Baits states that Paytren is dzalim and contains gharar. Paytren is a payment application in which those who have the application must pay while other application, for example Traveloka, is free. According to him, if Paytren gives the priority of the product or application, it is certain that other people must not possess the same application. If they buy the same application, they themselves will be able to use it and who becomes the consumers will be uncertain. This means that what is being important is not the products but buying the market opportunity which can generate profit or loss. The lowest level partner will suffer the greatest lost as the market opportunity is getting smaller and it is harder to get new partners. The detail comparison between Paytren MLM and Conventional MLM can be seen in table 1 .

\section{Table 1}

\section{Criticizing the Halal or Shariah Certificate of Paytren}

\begin{tabular}{ll}
\hline \multicolumn{1}{c}{ Paytren MLM } & \multicolumn{1}{c}{ Conventional MLM } \\
\hline $\begin{array}{ll}\text { 1. There is no target from the company } & \text { 1. Purchasing product is a must } \\
\text { 2. There is no closing point requirement } & \text { 2. There is closing point system in case the } \\
\text { 3. Goods stock is not a must } & \text { trade fails to run } \\
\text { 4. There is no bonus loss } & \text { 3. Goods stock is a must } \\
\text { 5. There is no membership time limit } & \text { 4. The bonus is lost when the member fails } \\
& \text { to recruit new members } \\
& \text { 5. There is membership time limit }\end{array}$ \\
\hline
\end{tabular}

The general procedure of Paytren MLM application is by selling, inviting and teaching, building organization, as well as developing and motivating. It can be seen as follows; first, the company tries to invite the consumers to be the members by asking them to buy the product package, that is the Paytren application or software. Second, the buyers will get a membership card from the company. Third, this new member, after being registered, should recruit new members according to those previous three-steps buying procedure followed by completing the membership form. 
If a member successfully gets many new members, he or she will receive a bonus and commission. The more members he or she gets, the more bonus and commission he or she will receive as the company gains a lot of profits from the new members who also becomes the consumers of the company. Through this recruitment will automatically upgrade the rank position of the older members and at the same time receive the promised bonuses.

In a muamalah context, Paytren as a MLM form is considered as mubah or permitted to conduct until found other regulations or fatwas that prohibite it; just like what a fiqh principle says:

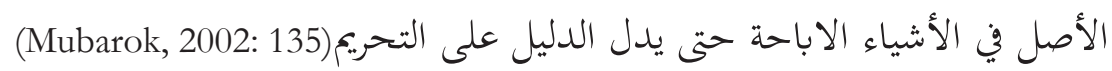

The reason why Paytren MLM permitted is because its has a real product. However, it is necessary to prove its status by looking for the dalîl or regulations which may be broken by Paytren, and one of them is the fatwa of MUI on PLBS. When observing the fatwa of MUI number 75/DSN/MUI/VII/2009 on PLBS, there are several terms in Paytren MLM which are not in accordance to the regulations; for example, the member must register and pay Rp 350,000,-to get a software application. This will inflict a financial loss to the consumers as it is not commensurate with the benefit acquired. As a result, it does not abide by the fatwa of MUI point $d$.

This also applies for the system of bonus or commission distribution which is based on the number of downline members, not on the performance. The more downline members successfully recruited by a member, the more bonus and commission he or she will receive. This also will put the upline members in advantageous position while the members in lower position will get disadvantage. This is not in accordance with legal regulation of MUI point e. This also breaks the regulation point $\mathrm{c}$ as it contains the element of zulm. It can be seen from the payment of commission to the upline members, who actually do nothing, by grabbing the commission for the downline members. This means, the downline members should pay give their bonus for the upline members, and so on and so forth.

The research finding also reveals that the bonus distribution is not clearly explained since the beginning of the contract. A new member who is on position of UP (User Package) 25 will never be able to find out what kind of bonus he or she will receive since he or she has not got the license. To get a license and get a basic position (higher than 
UP25), a new member must upgrade his or her position by paying Rp 325,000,- and recruit one new member. This is clearly against the regulation of DSN-MUI on SMDS point $f$ which states that the transparency of the number of bonus given during transaction which is based on the target of sales is a must. Even, this practice indicates gharar, especially in purchasing the license because there is no transparency for the downline partners on how many transactions they have done. As a result, they are unable to find out the operational system of new member recruitment and how much bonus they should receive.

Furthermore, in Paytren system, when a downline member conducts a transaction, the upline members will receive a bonus and commission although they do not perform any sales. This is certainly against the legal regulation of MUI point g. From this point, another research result shows that members of Paytren receive an unjustice conduct. The upline members get the bonus from what the downline members have done and this is against the legal regulation point i.

Paytren is indicated to conduct a money game activity by giving bonus or commission from the revenue of new member recruitment. This can be clearly seen from the upline members who perform nothing but they receive commission taken from what their downline members' transactions. This is against the legal regulation point 1 .

Table 2

Analysis of Paytren Agreement towards the Fatwa of DSN-MUI

\begin{tabular}{clll}
\hline Points & \multicolumn{1}{c}{ Regulations } & \multicolumn{1}{c}{ Reality } & \multicolumn{1}{c}{ Information } \\
\hline a & Real transaction exists & Yes & Conformed \\
\hline b & $\begin{array}{l}\text { Object is not something } \\
\text { considered haram or prohibited } \\
\text { and or used to perform } \\
\text { something prohibited }\end{array}$ & Yes & Conformed \\
c & $\begin{array}{l}\text { Contain no element of gharar, } \\
\text { maysîr, ribâ, zulm, ma'siyat }\end{array}$ & $\begin{array}{l}\text { Indication of gharar } \\
\text { and zulm }\end{array}$ & Doubtful \\
\hline d & There is no excessive mark up & $\begin{array}{l}\text { The registration fee } \\
\text { is not commensurate }\end{array}$ & Not Conformed \\
& & with the value & \\
\hline
\end{tabular}




\begin{tabular}{clll}
\hline Points & \multicolumn{1}{c}{ Regulations } & \multicolumn{1}{c}{ Reality } & \multicolumn{1}{c}{ Information } \\
\hline $\mathrm{e}$ & $\begin{array}{l}\text { The commission must be } \\
\text { based on job performance } \\
\text { andd become the main income }\end{array}$ & Downline-based & Not Conformed \\
\hline $\mathrm{f}$ & $\begin{array}{l}\text { The number of bonus must be } \\
\text { clear during the transaction }\end{array}$ & $\begin{array}{l}\text { No explanation } \\
\text { during the transaction }\end{array}$ & Not Conformed \\
\hline $\mathrm{g}$ & $\begin{array}{l}\text { There is no passive bonus } \\
\mathrm{h}\end{array}$ & $\begin{array}{l}\text { There is passive } \\
\text { bonus }\end{array}$ & Not Conformed \\
& $\begin{array}{l}\text { The commission and bonus } \\
\text { system does not result in igbrâ }\end{array}$ & Yes & Conformed \\
\hline $\mathrm{i}$ & $\begin{array}{l}\text { There is no exploitation } \\
\text { and unfairness in the bonus } \\
\text { distribution }\end{array}$ & $\begin{array}{l}\text { There is exploitation } \\
\text { and unfairness }\end{array}$ & Not Conformed \\
\hline $\mathrm{j}$ & $\begin{array}{l}\text { The member recruitment, } \\
\text { rewarding system and } \\
\text { ceremonial events do not } \\
\text { contains elements which are } \\
\text { against aqida, shariah, and } \\
\text { good deeds }\end{array}$ & No & Not Conformed \\
\hline $\mathrm{k}$ & $\begin{array}{l}\text { Every business partner must } \\
\text { develop and monitor the } \\
\text { newly recruited members }\end{array}$ & Not all & Doubtful \\
\hline $\mathrm{l}$ & $\begin{array}{l}\text { No money game } \\
\text { There is money game }\end{array}$ & Not Conformed \\
\hline
\end{tabular}

\section{Conclusion}

The certificate of halal or shariah issued by DSN-MUI towards Paytren needs more validity scrutiny, considering in reality there are several things which are not conformed to the legal regulations in the fatwa of DSN-MUI number 75/DSN/MUI/VII/2009 on PLBS. Out of twelve points, only four points conform with what Paytren has conducted while two points are still doubtful and six points are not conformed. It shows that DSN-MUI is not consistent with its fatwa since it has given a certificate of halal or shariah towards a product which has not fulfilled the criteria of halal. This can be an input for DSN-MUI to be more cautious in giving a halal certificate towards a product by performing an in-depth and comprehensive investigation before issuing the certificate. 
Ijtihad: Jurnal Wacana Hukum Islam dan Kemanusiaan, Volume 19, No. 2, Desember 2019: 169-183

\section{Bibliography}

Amin, Ma'ruf. Himpunan Fatwa MUI Sejak 1975. Jakarta: Emir, 2015.

Arum, Imam Mas. "Multi Level Marketing (MLM) Syari'ah: Solusi Praktis Menekan Praktik Bisnis Riba, Money Game.” Muqtasid 3, no. 1, 2012.

Dewanti, Ririn. "Kecerdasan Emosional dan Prestasi Kerja pada Distributor Multi Level

Marketing (MLM) K-Link Cabang Sidoarjo.” Psikologia 3, no. 1, Januari 2015.

Dewi, Gemala. Hukum Perikatan Islam di Indonesia. Jakarta: Kencana, 2005.

Dwyanita, Ajeng. Irham Zaki. “Analisis Kesesuain Syariah pada Sistem Operasi Bisnis Multi

Level Marketing (MLM) KK Indonesia dengan Fatwa DSN MUI No. 75/DSN-MUI/ VII/2009." JESTT1, no. 4, 2014.

Harefa, Andreas. Multi Level Marketing. Jakarta: Gramedia Pustaka Utama, 1999.

http://erwanditarmizi.com/harta-haram-muamalat-kontemporer/, diakses pada tanggal

24 November 2017, pukul 08.00 WIB.

http://www.paytrenluarbiasa.com/2017/01/tingkatan-kemitraan-paytren.html. bttp://youtu.be/10eXwDzdoP8, diakses Pada Tanggal 9April 2018, pukul 09.00 WIB.

http://youtu.be/5aOSOtcEUOQ, diakses pada tanggal 8 April 2018, pukul 09.00 WIB.

bttp://youtu.be/okjnjM3zoNc, diakses pada tanggal 8 April 2018, pukul 09.00 WIB.

https://kbbi.web.id, Kamus Besar Bahasa Indonesia (KBBI) Kamus versi online/daring

(dalam jaringan).Diakses Pada Tanggal 23 Januari 2018, pukul 08.00 WIB.

https://www.paytren.co.id/.

https://www.treni.co.id.

Jauhari, Sofwan. MLM Syariah: Buku Wajib Wirausahawan Muslim Praktisi MLM Syariah.

Jakarta: Mujaddidi Press, 2013.

Kamus Besar Bahasa Indonesia (KBBI) Versi Daring. n.d. https://kbbi.web.id. (accessed Januari 23, 2018.

Mandang, Cristian Leonardo. "Keabsahan dan Kekuatan Hukum Layanan Multi Level Marketing di Kota Manado.” Lex Privatum IV, no. 2, 2016.

Mochammad Rokim, Bronze Leader Paytren, Wawancara Pribadi melalui Whatsapp.

Mubarok, Jaih. Kaidah Fiqh, Sejarah dan Kaidah-kaidah Asasi . Jakarta: Raja Grafindo Persada, 2002. 
Nashirudin, Muh. "Fatwa MUI Bidang Ibadah dan Perannya dalam Kehidupan Berbangsa dan Bernegara." International Islamic Conferernce on MUI Studies. Jakarta: MUI, 2017. 553.

Purnomo, Serfianto D, Iswi Hariyani, Cita Yustisia. Multi Level Marketing, Money Game dan Skema Piramid. Jakarta: Elex Media Komputindo, 2011.

Al-Qardhawi, Yusuf. Syari'ah al-Islam, Khuluduba Wa Shalabuba li at-Tathbiq fi Kulli Zaman wa Makan. Batna: Dar asy-Syabab, t.t.

Rahmah, Lilatur. "Bisnis Multi Level Marketing dalam Tinjauan Fatwa DSN-MUI No. 75/DSN-MUI/VII/2009 (Studi Kasus pada Member MLM 4jovem di Situbondo)." Istidlal 1, no. 2, 2017.

Sulhan Mahfud, Star Leader Paytren, Wawancara Pribadi melalui Whatsapp.

Wawancara dan Sumber Online:

wwn.trenpeneur.com/Tentang/, diakses pada tanggal 20 Desember 2017.

Al-Zuhaili, Wahbah. "al-Ijtihad al-Fiqhi al-Hadis, Munthalaqatuhu wa it-Tijahatuhu.” In alIjtihad al-Fiqhi, Ayy Daur wa Ayy Jadid, by Muhammad al-Rouki. Cassablanca: an-Najah al-Jadidah, 1996.

Al-Zuhaili, Wahbah. al-Figh al-Islami wa Adillatubu. Vol. IV. Beirut: Dar al-Fikr al-Mu'ashir, 2005. 
